\title{
BARYMTA - AS AN INSTITUTION OF THE LEGAL SYSTEM
}

\author{
Karlygash Useinova $^{1 *}$, Aset Toktybaev ${ }^{1}$, Akylbek Isabekov ${ }^{1}$, Spatai Sartaev ${ }^{1}$, Aidar Zhainak ${ }^{1}$ \\ ${ }^{1}$ Al-Farabi KazNU, pr. al Farabi, 71, 050040 Almaty, Republic of Kazakhstan
}

\begin{abstract}
The article is devoted to the study of the Barymta Institute and determining its place in the customary legal system of the Kazakhs. The article shows the main stages of the emergence, development, and liquidation of Barymta; reveals the essence and content of the Barymta Institute; identifies and analyzes the main forms of Barymta manifestation. The ultimate goal of the legal reform carried out in Kazakhstan is the formation of the national legal system of the Republic of Kazakhstan. In many ways, its success depends on how much the legal heritage of the Kazakh people will be used. Traditional Kazakh society did not know written law. That is why legal regulations were of great social, regulatory and managerial importance. Without studying the customary law of the Kazakhs, developing specific, reasoned views on its nature, as many prominent scientists emphasize, it is impossible to comprehensively study the history of the people of the traditional period, especially since many issues remain completely unexplained.
\end{abstract}

\section{Introduction}

The first attempts to study the common law of the Kazakhs were made back in the XYIII XIX centuries. Thanks to the notes, notes, and works of such researchers of the region as N.A. Aristov, L.F. Balluzek, S.B. Bronevsky, S. Valikhanov, V.V. Velyaminov - Zernov, E.S. Wulfson, J. Gurland, A.I. Dobromyslov, M. Kozlov, N.I. Krasovsky, I.I. Kraft, A.I. Levshin, F. Leontovich, P.E. Makovetsky, G.N. Potanin, V.V. Radlov, P.P. Rumyantsev, N. Rychkov, L.A. Slovokhotov, I.P. Shangin, A. Yanushkevich, and others, huge empirical material was identified and collected. The foundation was created for further scientific research in this direction.

A significant contribution to the study of problems of Kazakh customary law was made by Kazakh enlighteners S.S. Valikhanov, I. Altynsarin,AbayKunanbaev, prominent representatives of the Kazakh intelligentsia A.N. Bukeikhanov, J. Dosmukhamedov, A. Baitursunov, J. Akpaev, B. Karataev and others.

\footnotetext{
* Corresponding author: karlygash_usein@mail.ru
} 
Interest in the customary legal system of Kazakhs increased in Soviet times. However, the studies conducted during this period in the field of the customary law of the Kazakhs were unilateral, class in nature.

With the acquisition of sovereignty and independence by Kazakhstan, a new approach has been outlined in the study and study of Kazakh customary law.

The common law of the Kazakhs, legal scholars are increasingly beginning to consider in the aspect of the development of the traditional legal culture of the nomadic society. Such studies include the works of N.L. Aitkulova, K.A. Alimzhan, S. Andabekova, N.S. Akhmetova, M.T. Baymakhanova, Z.D. Busurmanova, S. Dauletova, K.A. Zhirenchina, M. A. Ismailova, A.S. Ibraeva, Z.Z. Kenzhaliev, B.Z. Kuandykova, T.M. Kulteleeva, S.Z. Zimanova, S.N. Sabikenova, S.S. Sartaeva G.S. Sapargaliev, A.N. Taukeleva, S.F. Udartseva,D. H. Saidumova S. Uzbekuly, K.R. Useinova, N.U. Userova, G.R. Useinova, S.L. Fuchs and others.

\section{Methods}

When writing the article, general and private-scientific methods of scientific knowledge were used: dialectical, historical, comparative legal, system-structural, functional, logical-legal, etc.

With the help of general scientific and private scientific methods of cognition, a significant amount of monographic, special literature, historical-legal and political-legal documents are studied, which allows you to visually substantiate the reliability of scientific conclusions and results obtained in the course of the study.

\section{Discussion}

In scientific literature, the problem of the institution of Barymtyis very closely connected with the problem of implementing the norms of the traditional law of the nomadic Kazakh society.

The latter is controversial in the theory of the law of the traditional Kazakh society. There are several points of view. Some scholars believe that customary law in a traditional society was enforced voluntarily. According to other scholars, the coercive power of the state played a special role in the implementation of the rule of law. Representatives of the third movement are promoting the so-called "mixed" idea. They believe that the legal customs in the nomadic society of the Kazakhs were performed both voluntarily and forcefully. Despite the fact that all three points of view have a right to exist, the third is closer, since it objectively reflects the peculiarities of legal proceedings in the traditional nomadic society of the Kazakhs. Indeed, judicial decisions in a nomadic society could be enforced both voluntarily and coercively. However, in our opinion. coercion was provided not by the power of the state, but by the power of the tribal community itself. Barymta also acted as such a force [1].

Barymta, as the concept of a common Turkic legal culture, was a "legal regulatory institution based on the material and enforcement execution of court decisions" [2, pp. 269-270].

In its formation, barymta passed four stages (See Table 1).

Barymta as a manifestation of talion.

Judicial practice in the traditional society of many nations, studies show, was based on two basic principles of customary law, with the help of which disputed situations were resolved. This is the principle of retribution (talion) and the principle of composition (compensation). 
One of the main principles of traditional Kazakh law was the principle of the talion as one of the most effective ways of regulation.

It should be noted that the principle of the talion is characteristic of almost all legal systems in the initial stage of their development. The famous English scientist A.R. Radcliffe-Brown writes on this subject: "The injured group is believed to have reason for revenge, and it is often the responsibility of group members to avenge the murdered person.

Table 1. Main periods of formation and development of barymta in the legal system.

\begin{tabular}{|l|l|l|}
\hline №/№ & Name of the period & Brief description of the period \\
\hline 1 period & Protokazakh & $\begin{array}{l}\text { theprotokazakh Institute of barymta originated in ancient times, } \\
\text { even before the Oirat charters and "YASA Chinigiskhan" were } \\
\text { compiled, although the latter had a certain influence on the } \\
\text { development of this institution. }\end{array}$ \\
\hline $\begin{array}{l}2 \\
\text { Period }\end{array}$ & traditional Kazakh society & $\begin{array}{l}\text { during the reign of Tauke Khan, barymta became a legal way to } \\
\text { protect law and order. According to the Code of the Tauke } \\
\text { Khan, the right to barymta arose for the victim if the defendant } \\
\text { did not execute the sentence or court decision, as well as if the } \\
\text { elder of the family deliberately evaded the proceedings and thus } \\
\text { patronized the perpetrator. }\end{array}$ \\
\hline 3 period & $\begin{array}{l}\text { transformations } \\
\text { barymta under } \\
\text { influence of reforms of } \\
\text { the XIX century }\end{array}$ & $\begin{array}{l}\text { the tsarist government, based on the Regulations on the } \\
\text { administration of the Orenburg Kirghiz, Temporary provisions } \\
\text { of 1867 and 1868, and other laws, constantly sought to limit the } \\
\text { sphere of influence of Kazakh customary law }\end{array}$ \\
\hline 4 period & $\begin{array}{l}\text { liquidation of barymta } \\
\text { after the establishment of } \\
\text { Soviet power. }\end{array}$ & $\begin{array}{l}\text { despite the fact that tsarism declared barymta a crime, it was } \\
\text { liquidated only after the October revolution of 1917. }\end{array}$ \\
\hline
\end{tabular}

Barymta manifested itself in several forms.
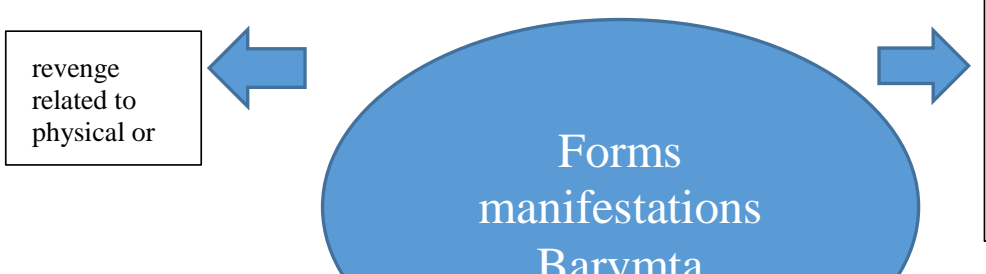

method of protection of thway to protect infringed law e violated
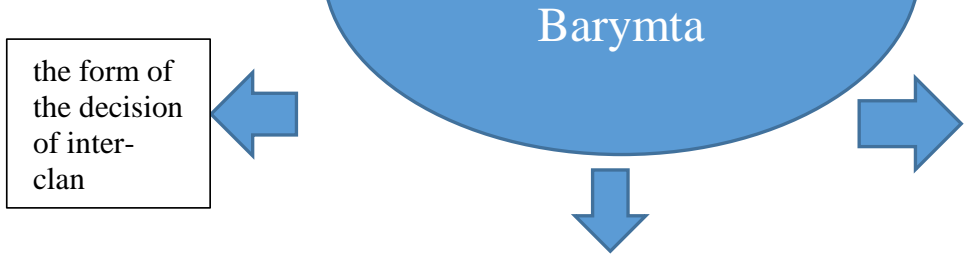

\section{form of social protest or discontent}

a means of punishing a deviation from the community's ancestral interests

Fig. 1. Forms of barymta manifestation.

The action of retaliation is regulated by custom: lextalionis (the law of the talion - equal retaliation) requires that the harm inflicted be equivalent to the inflicted ... "[3, p.248]. 
The principle of talion among the Caucasian peoples was especially vividly manifested. So, revenge in the Adyghe society was a public institution, the main purpose of which was the settlement of the conflict. Particularly, in our opinion, it should be noted that the choice of the form for resolving the conflict depended on many factors, but two aspects played the most important role in this - personal and social. However, unlike other peoples of the Caucasus, the Circassians in the second half of the XIX century, revenge ceases to be a duty. They begin to consider it as a right that can be used or not used.

Basically, among the Caucasian peoples, revenge existed in two forms: bloody and bloodless. This difference was based on the nature of the initial conflict. If blood was spilled as a result of the initial conflict, then the relationship between the parties to the conflict and the victim's relatives was considered as blood relations. If the basis of the initial conflict was the infliction of property damage, then the relationship was considered as hostile, i.e. bloodless. 188].

M. Kovalevsky also pointed to the connection between Barymty and the talion $[4, \mathrm{p}$.

In the traditional nomadic society of the Kazakhs, the talion was of a group nature. The object of retaliation could be any member of the clan community, an individual family, or the clan as a whole [5, p.27].

Given the foregoing, the following can be formulated.

- The principle of talionis based on the desire for justice.

"Talion is the first way to restore a violated right."

- The main thing in the talion is proportionality. It can manifest itself as the principle "eye for eye", "ear for ear", "blood for blood", "hoof for hoof".

- Talion was of a group nature on both sides of the conflict.

- On the basis of the talion, the institution of Barymta arose and existed [6, p.447].

One cannot disagree with this. The main thing in the talion is the desire to establish a balance by rewarding the perpetrator according to his merits, in fairness, and an objective desire to achieve justice. In this regard, it should be noted that one of the forms of talion manifestation was barymta.

Barymta as a way to resolve intergeneric disputes

In the XYIII-XIX centuries. newbarymta targets are being formed. Increasingly, tribal raids against each other are carried out, which are accompanied not only by cattle driving, but also by the capture of a large number of "donkeys". Barymta begins to acquire the character of tribal feudal wars. A vivid example of this is the frequent raids of Kazakh tribes led by sultans and batyrs on the possessions of Kalmyk princes. Almost all sources indicate the role of the batyrs in the commission of barymta.

It was believed that the participation of the batyr in Barymta is a service to the just cause. As a rule, the batyrs who took part in such raids enjoyed great fame, honor and respect among the Kazakh population. Here is what N. Rychkov noted on this occasion: "This atrocity does not only do no vice between them, but is also revered for signs of perfect courage and agility" [7, p. 26]. "Baranta is revered as daring," wrote Bronevsky. "Characterized by successful raids, they are glorified as heroes in folk songs" [8, p.164].

In considering this issue, a special role is played by the fact that Barymta was known not only to Kazakh traditional law, but also to the ordinary law of neighboring states. A similar form of barymta was known to the traditional law of the Bashkirs, Turkmens, Kyrgyz, and other peoples.

It is Barymta that is mentioned in the works of oral folk art of the Bashkir people. In particular, considerable attention was paid to this form of barymta in the Bashkir folk epos "Akbuzat". In contrast to the Kazakh society, where the emphasis is on barymta - as a way of protecting one's violated rights, in Bashkir traditional law, barymta was primarily 
perceived as a form of reflection of the property stratification of society, as a form of resolving intergeneric disputes. In this work it is very well shown.

Barymtais defined as a raid on a hostile tribe in order to seize wealth. Formally, participation in Barymtawas considered voluntary. However, those who shied away from participating in Barymta for any reason, the society condemned. Those who took part in such actions, with a successful outcome, received their share of the mined. L. Kazantseva on this occasion notes that the riders who distinguished themselves on the baranta for their courage and courage, acquired the name "batyr" [9, p. 39].

Barymta in Bashkir society performed several functions, the main of which were: unification of the tribe; improving the material condition of both the tribe as a whole and the clan separately.

There was a similar institute among the Turkmen, it was called "Alaman." It should be noted that initially the alaman was not just a raid to seize someone else's property, but, as a rule, the attack was carried out with the aim of revenge. This is precisely what related the alaman to the barymta.

In Kyrgyz traditional society, Barymta was born as a means of resolving tribal conflicts. As a rule, the initial basis for such conflicts was property damage suffered by one or another ail. Frequent small raids turned into large-scale military clashes with the aim of seizing territories and prisoners for use as slaves in the household.

As a rule, large cattle owners, having at their disposal dzhigits could start military operations at any time. Moreover, the following facts could act as grounds: revenge; protection of relatives; insults inflicted on a person as a member of a clan, tribe; cattle theft, which, when found guilty, led to clashes, and sometimes even to feudal wars.

Thus, revenge was the main cause of intergeneric feuds. Often revenge flares up to the point that, like a fire, it covers entire volosts and disturbs peace in the steppe for a long time [10, p. 411].

Some authors considered this custom to make barymyta wild. [11, p. 416]. Let us disagree with this point of view, since the barymta was a necessary measure. Relatives and friends should have participated in the barymta. Refusing to participate in the commission of barymta was considered by the Kazakhs as a great indelible disgrace.

Often in the traditional Kazakh nomadic society, the institution of barymta was used by conservative forces in internecine strife. As you know, all the basic tasks in peacetime were solved at the level of the clan, in order to strengthen their influence and satisfy ambitions, the tribal aristocracy organized various military actions dressed in the form of a barymta. One of the main conditions for the cessation of the tribe's activity was its inability to respond to the barymta. It is this form of barymty that began to take place in the Kazakh society in the XYIII - XIX centuries. This, in our opinion, can be explained, first of all, by the fact that clan and intergeneric relations began to weaken. Often raids were made not only on neighboring genera, but also on neighboring peoples. As a result, a large number of cattle were driven away, people were taken prisoner. Barymta became nothing more than a feudal raid and a means of profit. SeitKenzheahmetuly writes about such a form of barymta [12, pp. 40-41]. The well-known Kazakh writer M.O. Auezov in his story "Barymta" [13, p. 32-33].

One cannot but agree with L.P. Mayrom. He noted that the reason for the civil strife was always legal, since it was the reluctance of one of the disputing parties to submit to the decision of the biys court. As a result, the offended party had a legal right to achieve satisfaction by force, i.e. made an attack, drove cattle and captured people. In response, the stolen people paid the same, believing that more was taken from them than they should have been upon a court verdict [14, p. 253]. Thus, mutual theft and murder more and more confused this issue, and ultimately led to prolonged internecine wars. 
In general, evaluating the significance of this form of barymta, I would like to note that it was somewhat artificial in nature. It gained wide distribution in the period after the accession of Kazakhstan to Russia and was most often provoked by the Russian authorities, as it ultimately led to a radical destruction of the unity of clans and tribes. It is no accident that many Kazakh khans and sultans in the 19th century, reforming the clans and tribes subject to them, paid considerable attention to the barymta, which during this period could easily go into robbery and caused enormous damage to the Kazakh society.

Barymta as a way to protect violated rights

This form of barymta was necessary at certain stages of the historical development of society and the state.

Professor R. Syzdykova in her monograph "Words Speak" notes that they did not always go to barmymta out of revenge. In the absence of special law enforcement agencies, their function, as a rule, was performed by centuries-old customs. According to them, the victim had the right to compensation for damage caused to him by the other party. And if the offender who has stolen cattle does not obey the decisions of the authorities and refuses to voluntarily compensate for the damage, the victim takes a baryt and returns the loot with his own efforts. This is not condemned, but recognized as legitimate, because, thus, the injured party administers justice over lovers of easy money [15].

Indeed, the steppe civilization is fundamentally different from the western and eastern ones in that the state does not play a special role here. Societies related to the steppe civilization, as a rule, are declassified and functioned mainly as civil. The behavior of an ordinary member in such a society was regulated with the help of certain rules based on customs (steppe democracy) [16, p. 89].

Thus, the Kazakh traditional society was a civil society, the main principles of which were: self-government, self-development and lynching.

Barymta, first of all, is the institution of Kazakh customary law, for the fulfillment of which an occasion was necessary, and for the recognition of its lawfulness - compliance with certain conditions governed by traditional Kazakh law. About this, first of all, wrote S.S. Valikhanov.

During the reign of Khan Tauke, one of the directions of his political and legal activity was the strengthening of Kazakh statehood. It was during this period, as S.L. Fuchs, Barymta "is characterized by its transformation into a legal way of protecting the rule of law" [17, $p$. 607]. According to the Code of Khan Tauke, the victim had the right to a barymta if the defendant did not execute the verdict or court decision, as well as if the elder of the family deliberately avoided the trial and thereby patronized the guilty. Some authors - researchers note that in the judicial procedural meaning this institution began to be applied at the end of the XYIII - the beginning of the XIX century in connection with the deepening of the feudalization process of the Kazakh society and the weakening of the tribal principles. We will allow ourselves to disagree with this opinion, since initially (XYII century) the barymta "was characterized by the limitation of elements of arbitrariness, its regulation and turning into a legal way of protecting the rule of law" [18, p.132]. Thus, Barymta was a way of securing and enforcing a bii court decision. And in this sense, the Barymta is as old an institution as the institution of violence.

Barymta was a kind of judicial procedural mechanism for attracting the rejecting party to legal proceedings $[19, \mathrm{p} .126]$. Thus, a person who has a reason to demand payment of a debt or remuneration has applied such a claim to a debtor. If the debtor refused to pay, the creditor, as a rule, redirected his claims to the next of kin or to the most honorable and respected members of the debtor's family.

It should be noted that the cases of voluntary fulfillment of the obligation, although they did occur, however, were not so frequent. Almost all researchers note that, as a rule, 
negotiations dragged on for years, and only having lost hope of the possibility of a peaceful settlement of the conflict, the offended turned to the Rodovitch, announced to them his claim and the unwillingness of the opponents to satisfy it. Only after this did the Rodoviches form an armed group and sent for cattle theft, most often from one of the reputable elders of the opposite side, thus artificially forced the aksakal to intervene in the case and deliver offended satisfaction [19, p.126].

It was especially noted that a similar legal tradition existed in the 19th century among Chechens, Karachais, and the peoples of Dagestan. Thus, we see that the barymta among certain peoples of the Caucasus appears in one single form, namely: as a way to protect the violated right and is not cattle theft, but the arrest of property. However, in fairness it should be noted that not all Caucasian peoples had this state of affairs. So, among the Ossetians, barymyta was understood, firstly, as a crime in the sense of ordinary robbery; secondly, the arrest of another's property before the court in order to secure the rights of the creditor; thirdly, military capture; fourthly, punishment; fifth, a way to enforce a court sentence; sixthly, the right of the relatives of the slain to seize the killer's property until bloodshed; seventh, the right of the prince to take property from subservient people.

This institute among the Caucasian peoples was subjected to a detailed analysis in the works of M. Kovalevsky [4, p. 183]. The scientist especially noted that the barymta among the Caucasian highlanders was passive. This was expressed, first of all, in the fact that the Caucasian Barymtachs, by their customs, unlike Kazakh customary law, never went to the defendant's village, but rather, waited for one of his relatives to pass the plaintiff's village. If the plaintiff nevertheless waited for them, then he could, with the help of his relatives, take away from the defendant's relatives everything that was with them, namely: horses, weapons, money, etc. All the selected property remained in the plaintiff's aul as collateral until the defendant fulfilled his obligation.

Unlike the traditional law of the Kazakhs, the Caucasian peoples did not have any conditions for holding baryms.

Thus, taking into account the above, it should be noted that this form of barymty took place not only in the traditional Kazakh society, but also in the traditional society of the peoples of the Caucasus. They resorted to barymte in cases of dissatisfaction with legal requirements in the absence of any opportunity to achieve satisfaction in another way, without resorting to barymt. However, carrying out this form of barymty among the Kazakhs had certain features. Results

Based on the study and analysis of the essence, content and forms of barymty, we came to the following conclusions.

The basis of legal proceedings in traditional Kazakh society is the desire to achieve a certain balance, balance in society through compromise. However, a compromise in understanding nomads is not just a system of concessions. First of all, this is the desire to establish and maintain stability in traditional Kazakh society.

Enforcement of the court's decision was ensured by all the available power of the khanate, but was assigned directly to the plaintiff. The public opinion condemned not only the defendant, but also his relatives and the entire clan community as a whole for evading the execution of a court decision by biys. In the absence of a developed system of executive power, a court decision was often not voluntarily enforced. That is why, already in ancient times, the institution of Barymty emerged as a way to ensure the implementation of a court decision of biys or other legitimate claims that are not executed by the defendant. Barymtawas carried out by stealing the cattle of the guilty, his influential relative or village.

The Barymty Institute arose in ancient times. During the reign of Khan Tauke, Barymta became a legal way to protect the rule of law. According to the Code of Khan Tauke, the victim had the right to a barymt if the defendant did not execute the verdict or court decision, 
as well as if the elder of the family deliberately avoided the trial and thereby patronized the guilty.

Based on the analysis of the essence and content of the barymta, it was established that the barymta appears in several forms.

Barymta is, firstly, revenge associated with physical or mental harm; secondly, a means of punishment for moving away from community clan interests; thirdly, a method of protecting the violated right or a method of ensuring the defendant's appearance in the biys court, or a method of coercion to enforce a bii court decision; fourthly, a form of social protest or discontent; fifthly, a form of resolving intergeneric disputes.

Initially, Barymta emerges as a form of talion exercise. In traditional Kazakh law. The principle of talionis manifested as one of the most effective methods of regulation

Often the Barymty Institute was used by conservative forces in internecine strife. As you know, all the basic tasks in peacetime were solved at the level of the clan, in order to strengthen their influence and satisfy ambitions, the tribal aristocracy organized various military actions dressed in the form of a barymyta. One of the main conditions for the cessation of the tribe's activity was its inability to respond to the barymtu. It is this form of barymty that began to take place in Kazakh society in the 18th-19th centuries.

In traditional Kazakh society, barymta was widely used as a way to protect violated rights. This form of barymty, as a rule, took place in cases of non-satisfaction of legal requirements in the absence of any opportunity to achieve satisfaction in another way. In this sense, it is similar to the institution of "restitution" in Roman civil law.

Barymta was considered legitimate under the following conditions: firstly, the elder of the clan had to be informed in advance about the barymta; secondly, the open presentation of their claims; thirdly, the proportionality of the stolen cattle to the price of the claim; fourthly, the performance of barymyt during the day; fifth, stolen cattle had to be kept until the claim was satisfied.

\section{References:}

1. Useinova K. R. Barymta Institute and its place in the legal system of the Kazakhs: Diss .Ph. D.-Almaty, 2007

2. Zhumaganbetov T. S. Problems of formation and development of the ancient Turkic system of statehood and law. YI-XII centuries-Almaty, 2003

3. Radcliffe-brown A. R. Structure and function in primitive society: Essays on theory and lectures. - Moscow, 2001

4. Kovalevsky M. M. Modern custom and ancient law / / Customary law of Ossetians in historical and comparative coverage,71-187, 1886

5. Sarsenbaev N. S. Custom, traditions and public life. - Alma-Ata, 1974

6. Userov N. U. Structure and content of "Zhety-Jargy" / / Ancient world of Kazakh lawAlmaty, 430-453, 2005

7. Rychkov N. Daily notes of travel in the Kirghiz-kaisat steppe in 1771. - SPb., 1772

8. Bronevsky S. I. Notes of major General Bronevsky about the kirigz-kaisaks of the Middle Horde / / OtechestvennyeZapiski. - SPb., 123, 162-164, 1830

9. Kazantsev I. Description of Kirghiz bothropsatrox. - Kazan, 1904

10. Wulfson E. S. How the Kyrgyz are managed and judged / / the Ancient world of Kazakh law. - Almaty, 408-412, 2005

11. Dobromyslov A. Court of the Kirghiz during the Khan's administration / / Ancient world of Kazakh law. - Almaty, 412-417, 2005 
12. Kenzheakhmetuly S. Kazakh folk traditions and rites. - Almaty, 2000

13. Auezov M. O. Barymta / / Space 8, 32-43, 1961

14. Meyer L. P. Public and private life of the Kyrgyz / / Ancient world of the Kazakhs. Almaty, 6, 247-255, 2005

15. Syzdykova R. Words speak. - Almaty, 1997

16. Ibraeva A. S. Legal culture: problems of theory and practice. - Almaty, 2002

17. Fuchs S. History of Kazakh law according to Russian sources of the XVIII-XX centuries. // Ancient world of the Kazakhs. - Almaty, - Vol. 2. - Pp. 607-628 2004

18. Useinova G. R. State-legal views of Valikhanov CH. CH.: Dis ... kand. the faculty of law. Sciences: 12.00.01. - Alma-ATA, 1996

19.Zhanisov A. T., VestnikKazNU. Legalseries. 2, 125-127, 2003 